\title{
Application of supplier collaborative management in a Cuban commercial chain
}

\section{Aplicação da gestão colaborativa de fornecedores em uma cadeia comercial Cubana}

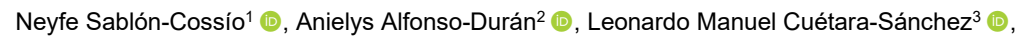
Yadamy Rodríguez-Sánchez ${ }^{4}$ (1)

\begin{abstract}
'Universidad Técnica de Manabí, Instituto de Posgrado, Grupo de Producción y Servicios, Portoviejo, Ecuador. Email: nsabloncossio@gmail.com

2Grupo AZCUBA, Departamento de Ventas, Matanzas, Cuba. E-mail: anielys.alfonso@tajae.azcuba.cu

${ }^{3}$ Universidad Técnica de Manabí, Facultad de Ciencias Administrativas y Económicas, Portoviejo, Ecuador. E-mail: leonardocuetara@gmail.com
\end{abstract}

${ }^{4}$ Universidad de Matanzas, Facultad de Ciencias Empresariales, Matanzas, Cuba. E-mail: yadamy.sanchez@umcc.cu

How to cite: Sablón-Cossío N., Alfonso-Durán, A., Cuétara-Sánchez, L. M., \& Rodríguez-Sánchez, Y. (2021). Application of supplier collaborative management in a Cuban commercial chain. Gestão \& Produção, 28(2), e4748. https://doi.org/10.1590/1806-9649-2020v28e4748

\begin{abstract}
Suppliers' management is an international practice which focuses on the interrelation between a supplier and a customer; therefore, the need for collaboration arises due to the extension of business boundaries. In this regard, this article aims to apply a procedure that facilitates the management of suppliers collaboratively within a Cuban commercial chain. This begins with the study of the commercial chain and its suppliers, respectively. Then, the business diagnosis continues with the evaluation of the suppliers based on a criteria matrix and concludes with a collaborative proposal. A collaborative supplier procedure adjusted to the conditions of the Cuban market is designed. This research presents a practical - methodological value because of the praxis of collaborative supplier management within a Cuban commercial chain.
\end{abstract}

Keywords: Suppliers; Management; Commercial chain; Customer.

Resumo: A gestão de fornecedores é uma prática internacional que privilegia a inter-relação entre fornecedor e cliente; Portanto, a necessidade de colaboração surge devido à extensão das fronteiras de negócios. Neste sentido, este artigo visa aplicar um procedimento que facilite a gestão de fornecedores de forma colaborativa dentro de uma cadeia comercial cubana. Isso começa com o estudo da cadeia comercial e seus fornecedores, respectivamente. Em seguida, o diagnóstico do negócio continua com a avaliação dos fornecedores com base em uma matriz de critérios e conclui com uma proposta colaborativa. É desenhado um procedimento colaborativo de fornecedores ajustado às condições do mercado cubano. Esta pesquisa apresenta um valor prático-metodológico pela práxis da gestão colaborativa de fornecedores dentro de uma cadeia comercial cubana.

Palavras-chave: Fornecedores; Gestão; Cadeia comercial; Cliente. 


\section{Introduction}

Supplier management is adapted to environmental conditions and the needs of supply chains. The management is currently focused on the collaborative relationship between the service and the product suppliers (Holweg et al., 2005; Melo \& Alcântara, $2015)$ to meet the needs of customers. This is due, to some extent, to the globalization of chains. Then, the interest in collaboration arises as a tool for improving competition (Calle Vicente et al., 2016).

Collaborative suppliers' management is based on identifying the customers' needs, the development of supply programs, establishing contracting processes and evaluating them together (Urbano Guerrero et al., 2016).

In the context of supply chains, and especially commercial ones, the suppliers' management process is an element of success or failure within the chain. This is because it directly influences the correspondence between purchases and sales adjusted to the client's needs (García Alcaraz et al., 2008). At the same time, the quality, time, quantity, and price of supplies are incorporated (Cano Olivos et al., 2015; Vizzoto \& Caixeta, 2019).

In previous studies carried out on the management of suppliers within the development of the chains, the following limitations have been identified: the low correspondence between the clients' needs and requests, the absence of suppliers' evaluation, little integration among suppliers, the whip effect increase (Li et al., 2017), insufficient information to make decisions in the field of supplies, division among suppliers and companies within the same chain. These elements do not stray from the chain, which is the object of study. It is a commercial chain with national and international scope settled down in Cuba. It focuses on the wholesale and retail market with eighty companies, ten territorial branches in the country, and specialized divisions. It features a variety of one-thousand products representing approximately the $60 \%$ of the national market segment. The fundamental problem lies in the difference between the products that are purchased and those that are demanded by the customer, and specifically, this influences the low disposal of products, the variety and quality, the high prices and the extended cycles in the chain's processes. This is causally related to inadequate supplier management in the Cuban commercial chain.

Considering the above explanation, the objective of this article is to apply a procedure that facilitates collaborative supplier management within a Cuban commercial chain.

As background to this research, it is made up of studies published by Alfonso Durán (2011).

\section{Conceptualization of suppliers' management}

Supplier management is defined as the supplier evaluation and selection processes, the classification and documentation of the supplier relationship, supplier performance management and classification (De La Hoz Granadillo et al., 2016; Sacomano \& Pires, 2012).

Another element to analyze is the interrelation between the suppliers' management and the study of request; specifically, the analysis of the supply market, the monitoring of trends in consumption and the marketing of the production in order to achieve offers from current or potential suppliers (Gil Saura et al., 2009). As the number of suppliers 
increases and request diversifies, there are risks with the suppliers' management (Infantes Díaz et al., 2015):

- Request management does not provide the basic guidelines to rationalize spending; therefore, the levels of capacity to contract from suppliers are improvised.

- Existing contracts are too inconsistent and do not quantify goals.

- Contracts have requirements based on the relationship of quality and price, so negotiations with suppliers become conflictive.

- There are delays or quality reductions in the supply.

Additionally, the negotiation of new contracts based on the constancy of financial agreements and quality is another element to take into consideration (Alzate Rendón, 2015). This includes ensuring compliance and alignment with contracts being updated (Uribe Macías et al., 2016). These contracts are aligned with the organization's business, strategy and needs (Alzate Rendón, 2015; González Correa, 2016). On the other hand, it is necessary that the information related to the providers and the service they offer is available and updated (Gil Saura et al., 2009; Hernández et al., 2016), with the goal of a follow-up based on the agreements.

From another perspective, there are procedures of the Quality Management System that regulate the evaluation of internal and external suppliers (López Torres \& Ortega Hernández, 2017). In this sense, the internal supplier is part of the department, unit or internal area of the organization; on the other hand, the external one is specified in the transactions of goods or services (Alfonso Villaquirán \& Ospina, 2016).

Due to the suppliers' selection need and evaluation, there is a group of indicators that can be used, (Quang et al., 2016): among them the general reputation of the supplier, the financial conditions, the flexibility of the supplier, the experience with the supplier in similar situations, the technical service offered, the trustfulness with the seller, the comfort in the supply of the order, the information available regarding the adequacy of the order, the price, the technical specifications, the easiness of use of the product, the preferences of the main user of the product, the information offered by the supplier, the confidence in the promised delivery date, the easiness of maintenance, as well as the after-sale service (Urbano Guerrero et al., 2016). In correspondence with the proposed indicators described, it is necessary to develop a procedure that facilitates the implementation of this logistics process in commercial chains.

In relation to the administration of suppliers, the trend in the state of the art and practice, demonstrates the need to strengthen relationships, based on true strategic alliances and collaborative agreements that facilitate the integration of supplier system processes-client. Currently, this mode of action is considered one of the world-class management practices (Quang et al., 2016).

\section{Collaborative planning with suppliers}

Current competitive requirements focus organizations on adopting collaborative strategies throughout their source chain (De Sousa Batista et al., 2016), with the aim of improving their performance and collaboration between organizations evolved from their strategy. It goes through the stages from functional integration of each area of the organization, the internal one between the functional areas in the form of an internal supply chain and the external one among suppliers, the internal supply chain and the customers (Freitas et al., 2019; Muñoz Aguilar \& Roldan Zuluaga, 2016). Therefore, 
nowadays, the logistics approach becomes a value-generating agent, based on a solid integration of the supplier-organization-client triad (Hazen et al., 2016).

However, to establish long-term collaborative relationships, it is necessary, first of all, to permanently evaluate and select the best suppliers, based on the level of comprehensive performance that they offer around the multiple criteria that the strategy of operations of the organization (client) aims to achieve the long term (Calache et al., 2019; Vizzoto \& Caixeta, 2019). In this sense, the decisions regarding the selection of suppliers do not focus directly on those who offer the lowest price and the best quality of the materials or services they offer, as other criteria, such as the delivery time, flexibility, reliability and service have already taken an important place against the current competitive challenge (Muñoz Aguilar \& Roldan Zuluaga, 2016; Viana et al., 2014). Therefore, selecting the best suppliers is a multi-criteria decision with a strategic impact.

The collaborative planning concept applies to both the planning process that extends to customers and the supplier process (Duke et al., 2017). The main objectives of collaborative supplier management are to provide the maximum added value at the lowest cost in relation to the needs of end customers (Castro Castell, 2015).

Sometimes, suppliers must monitor the inventories of their clients, as a more advanced way to manage warehouses and supply cycles alternatively (Ripoll Feliu \& Dickinson González, 2015). In this environment of the supplier's participation into the business of a given company, it is that the franchise or consignment modalities are presented, as the different activities and responsibilities are outlined with inventories and supply management (Adamu Nandonde \& Kuada, 2016).

Supplier's management is related to other processes within the collaboration, such as collaborative purchasing (Urbano Guerrero et al., 2016). In addition, with the correspondence between the needs of the clients and the proposals of the suppliers, it allows characterizing this process as collaborative (Calle Vicente et al., 2016).

In the selection of suppliers, two approaches are applied as indicated (Vieira \& Bonifácio da Silva, 2016): selection of supplier for a specific purchase and selection of suppliers to establish stable links for certain supplies. In these cases, the contracting of a medium or long-term supplier can establish jointly plans with the supplier's value improvement (Vieira \& Bonifácio da Silva, 2016).

Consequently, the determination of the indicators to be considered in the collaboration of suppliers is necessary (Fergusson Álvarez et al., 2016). In addition, it should be considered that the accelerated development of information systems, collaborative consumer's demand, where a greater amount of service, quality, delivery, technology, time and increasing global competition are demanded, it forces organizations to urgently adapt to the markets (Barreiros Porto, 2016). This leads to the need to adopt innovative forms of relationship with suppliers (Infantes Díaz et al., 2015), such as the collaborative practices targeted in this article.

The mutual benefit in the collaborative relationship with suppliers, (Urbano Guerrero et al., 2016), is identified with the following aspects: establishing relationships that allow a balance between profits in the short term, with long-term considerations; consultation and exchange of experiences and resources between suppliers and customers; identify and select key suppliers; share information and future plans; establish and unify the improvement and development of activities; inspire, motivate, recognize improvements and achievements of suppliers.

It is known that the commercial chains have the objective of achieving the integration and collaboration of their suppliers (Urbano Guerrero et al., 2016). This, as 
part of a strategy to obtain a good positioning in the market from processes with shorter cycle times, reduction of operation and administration costs, elimination of excess inventory, use of space while maintaining adequate inventory levels, guarantee of delivery cycles and control of goods in transit (Hazen et al., 2016).

The commercial chain needs suppliers to maintain their level of activity (Melo \& Alcântara, 2015) and; consequently, the needed integration within the organization, or group within an association, in which both sides benefit. In the study, the theoretical elements are included and adapted to the Cuban application context, and considering this aspect as the most relevant in the present research.

\section{Research methods and procedures}

\subsection{Description of a procedure for the study of collaborative supplier's management in a commercial chain}

The description of a procedure for the study of collaborative supplier's management in a commercial chain consists of three stages with their particular activities, Figure 1. This study is descriptive and correlational, and the composition of a set of quantitative and qualitative techniques is evidenced.

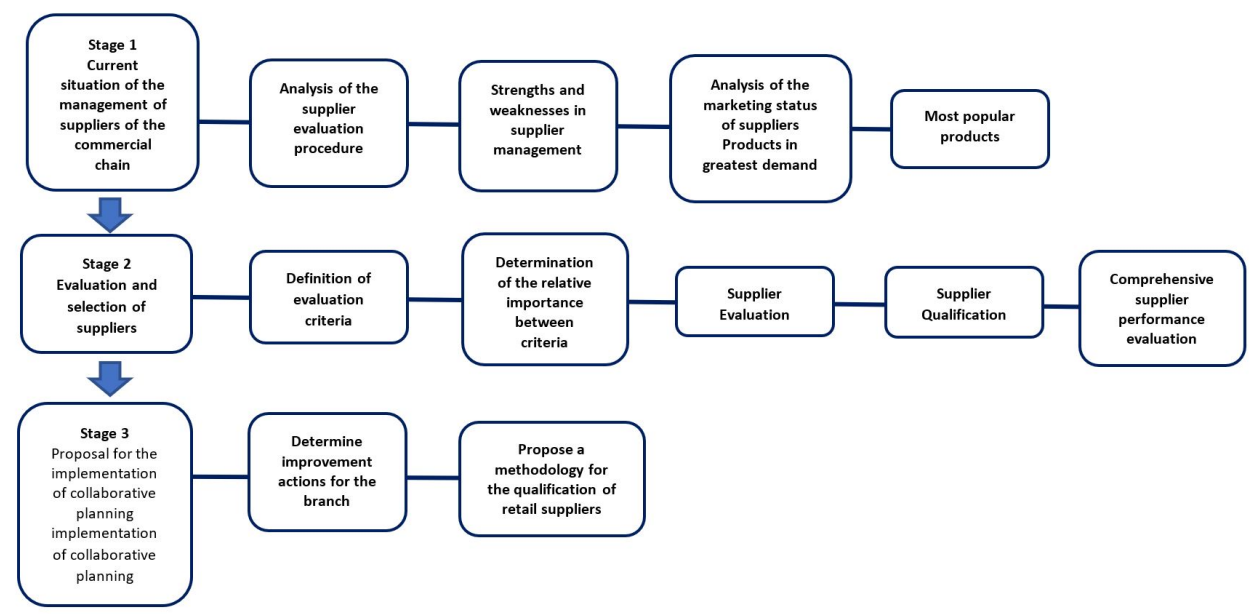

Figure 1. Proposed methodological procedure for the study of collaborative supplier management in a commercial chain. Source: Adapted from Alfonso Durán (2011).

The description of the main preliminary results in relation to the implementation of the methodological procedure is detailed below:

\section{Stage 1: Current situation of the supply management of the commercial chain}

In the first stage, its content is structured in four activities. These identify the current conditions of supplier management in a Cuban commercial chain. 


\section{Activity: Analysis of the supplier evaluation procedure}

The documentation of the management of suppliers in the commercial chain (object of study) is analyzed to identify the criteria that are considered in the evaluation of suppliers. This analysis is a way of determining which are the indicators, criteria and requirements for the evaluation and revaluation of the organization's suppliers through the documentary study.

\section{Activity: Strengths and weaknesses in supplier management.}

The strengths and weaknesses faced by the commercial department are determined considering, the criteria of the working group and the results of the checklists applied in this department. Subsequently, the main factors that influence supplier management are determined and summarized in a cause-effect diagram. The checklist is subdivided into suppliers, purchases, and negotiations, both with the commercial chain and with customers (Acevedo Suárez, 2017).

\section{Activity: Analysis of the status of sales.}

To identify the most demanded products according to essential sales and suppliers using the Pareto method (Dávila Aragón et al., 2016). The identified products are classified according to the criteria of their purchasing habits, their duration and tangibility (Kotler, 2016).

\section{Activity: Analysis of the marketing status of suppliers}

The different existing suppliers in the source segment in which the commercial organization is interested are identified and their deficiencies are recognized, too. The percentage value represented by the supply sources of the total purchases and sales is analyzed, determining which are the most important suppliers. Based on the preliminary results, the weaknesses manifested by the working group with the selected suppliers have been examined.

\section{Stage 2. Evaluation and selection of suppliers}

The problem is evaluated, and the set of critical suppliers is determined, based on a comprehensive assessment of their performance.

\section{Activity: Definition of supplier evaluation criteria.}

A rating scale is defined for the criteria for qualifying suppliers. The Kendall method is used based on the opinion of a group of specialists, and recognized in the subject of this research. For the selection of specialists, a few variables are considered such as: experience, knowledge, creativity, and willingness to work. 
Activity: Determination of the relative importance between the different criteria.

The definitive weight value is identified for each of the selected criteria, the weighted sum method was used, along with the Fuller's triangle and the Delphi method.

\section{Activity: Supplier evaluation}

Suppliers are evaluated, which is the object of study of the research. The qualification of the set of suppliers is carried out, it is related to each of the selected criteria, the scale selected for this process is applied, it is identified in Activity 2.2. The criteria matrix is elaborated in relation to each of the suppliers and it is standardized and proceeds to its normalization (Sarache Castro et al., 2009).

\section{Activity: Qualification of suppliers}

Suppliers are rated on a weighted basis, applying the weighted sum method, (Galarza Molina et.al., 2011), as specified in the following mathematical expression (Equation 1):

$$
C(A i)=\sum_{j=1}^{m}\left(W_{j}^{*} R_{i j}\right)
$$

Where:

$C$ (Ai): weighted rating obtained for provider $i$

$\mathrm{R}$ ij: supplier i score, with respect to criterion $\mathrm{j}$.

$\mathrm{W} \mathrm{j}$ : definitive weighted value of criterion $\mathrm{j}$

m: number of criteria.

The most critical cases of suppliers for the organization are identified, according to the quantitative value of the weighted rating obtained $\mathrm{C}(\mathrm{Ai})$ respectively.

Activity: Comprehensive evaluation of supplier performance.

Based on the results, a comprehensive evaluation of the suppliers' performance is carried out.

\section{Stage 3: Proposal for the implementation of collaborative planning with suppliers.}

A proposal for a set of improvement actions is prepared for its subsequent implementation, with the intention of promoting collaborative supplier management.

Activity: Develop a methodology for the qualification of suppliers in a commercial chain based on the application of multi-criteria methods.

The procedure described in the preceding stages is implemented in a systematic way by the retail chain, with the purpose of improving its management and facilitating 
the decision or judgment process, in relation to the selection of the supplier that satisfies compliance with the business objectives of the organization.

\section{Results and discussion}

The methodology for the study of supplier's management is applied within a Cuban retail chain of national and international scope. It gives service in different hotel groups that operate in sun and beach tourist destinations, in airports offering DUTIFREE services, as well as in corporate groups, warehouses, markets throughout the country and in strategic locations for foreign trade.

Supplier's management is a basic issue for the service providing process in hotel organizations and markets, since the main activity is buying and selling, both in the marketplace (to foreign suppliers), as well as to international and national suppliers. The chain under study presents a retail and wholesale activity; nevertheless, this article focuses on the first one.

The management of suppliers in this commercial chain presents a number of difficulties such as: the instability of products that affects the delivery of the order to the retailers (low level of availability for the customer), insufficient assortment of products based on demand, deficiencies in the transportation of the merchandise in the established time, low quality of products as an effect of the purchase at very low prices in the international market, in the case of fresh and frozen products, the distribution and transportation in an inadequate way affects the conservation of the themselves, the risk of unique merchandise suppliers (when their logistics fail, the client cannot find the product), among other relevant aspects, which evidenced the need for the investigation.

The retail commercial chain under study is made up of more than 210 suppliers, and they focus on the distribution of food, beverages and cleaning, which represent $80 \%$ of retail sales, with a high representation of national suppliers, such as it is observed in Figure 2. It is valid to specify that, although they are national producers, their fundamental raw materials are imported, making it a weakness when it comes to marketing and delivering it to customers.
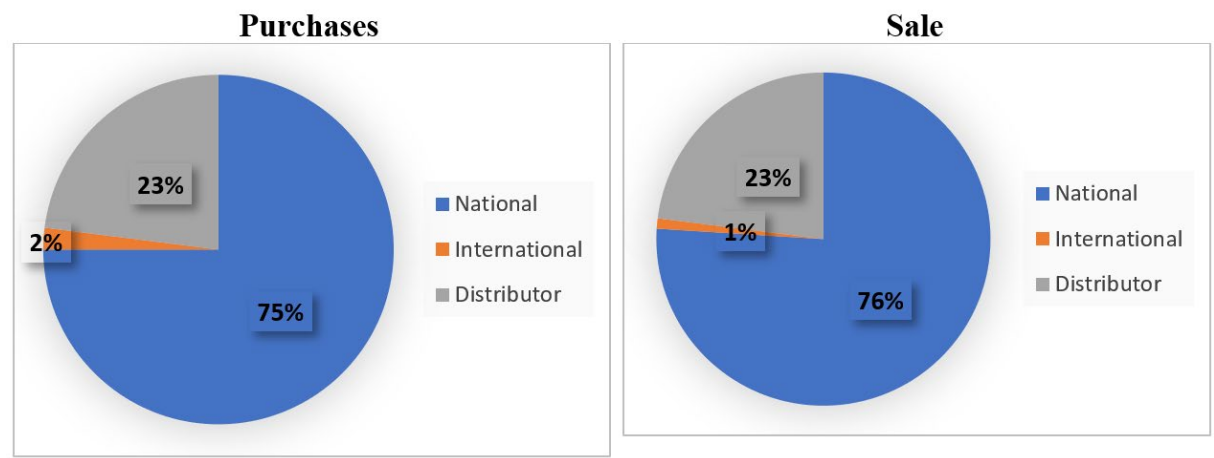

Figure 2. Behavior of purchases and sales in relation to supplier management. Source: Own elaboration because of the database of the chain under study.

Of all the suppliers, $15 \%$ are evaluated using the multi-criteria method, these are related due to the impact they represent on sales. The most experienced specialists in the organization are selected and defined according to the Kendall method (Wang et al., 2017): merchandise availability (C1), quality level of the products supplied 
(C2), correspondence between quality-offer-price (C3), stability of merchandise replenishment (C4), level of supplier-customer cooperation (C5) and delivery cycle (C6).

The supplier evaluation process begins with the first purchase, considering several indicators: conformity with the technical characteristics of the products, the level of customer satisfaction, value for money and payment facilities. Subsequently, suppliers are revaluated during operations based on the same criteria already mentioned. On the other hand, the strengths, and weaknesses of the supplier's management of the case study are identified and the results are integrated into the following elements of assessment:

1. Strengths: work experience, adequate communication with suppliers, a wide commercial network that allows representative purchases from suppliers, and an automated management system that allows obtaining a series of historical data necessary for placing orders.

2. Weaknesses: Sellers' facilities are not visited frequently; the management of providers presents a $\mathrm{n}$ insufficient monitoring of the performance indicators of the service. Therefore, if there are delays or decreases in the quality of the supply, it will not be able to act effectively to correct it. The demand for products delivered to national suppliers does not correspond to the actual behavior of the product; the supplier's evaluation is not carried out regularly and there are difficulties in the process of organization and planning of demand according to market requirements.

The results of the evaluation of the specialists, express a coincidence in $96 \%$ of the times, in the identification of the criteria $\mathrm{C} 1, \mathrm{C} 2, \mathrm{C} 3$ and $\mathrm{C} 5$; therefore, the validity of the proposed procedure is demonstrated, Table 1.

Table 1. Rating scale of the different decision criteria.

\begin{tabular}{|c|c|c|c|c|c|}
\hline Criterios & $\begin{array}{c}\text { Excellent } \\
\text { (1) }\end{array}$ & $\begin{array}{c}\text { Very } \\
\text { good (2) }\end{array}$ & Good (3) & $\begin{array}{l}\text { Regular } \\
\text { (4) }\end{array}$ & Bad (5) \\
\hline C1. Merchandise availability & & & & & \\
\hline $\begin{array}{l}\text { C2. Quality level of the } \\
\text { products supplied }\end{array}$ & & & & & \\
\hline $\begin{array}{l}\text { C3. Correspondence } \\
\text { between quality-offer-price }\end{array}$ & & & & & \\
\hline $\begin{array}{l}\text { C4. Stability of merchandise } \\
\text { replenishment }\end{array}$ & & & & & \\
\hline C6. Delivery cycle & & & & & \\
\hline Criterios & High (1) & $\begin{array}{l}\text { Medium } \\
\text { (2) }\end{array}$ & Low (3) & & \\
\hline
\end{tabular}

Source: adapted from Alfonso Durán (2011).

The determination of the objective weight (Wo) of each of the criteria was calculated based on the entropy method, completing these two steps: calculation of the entropy of each criterion by Silva et al. (2017) and calculation of the dispersion of each criterion, Table 2. 
Table 2. Application of the entropy method to calculate the objective weight of the criteria.

\begin{tabular}{lccc}
\multicolumn{1}{c}{ Criterios } & Ej & Dj & $\begin{array}{c}\text { Target } \\
\text { weight (Wo) }\end{array}$ \\
\hline C1. Merchandise availability & -15.0064 & 14.0064 & 0.2389 \\
\hline C2. Quality level of the products supplied & -11.7613 & 10.7613 & 0.1836 \\
\hline C3. Correspondence between quality-offer-price & -4.6666 & 3.6666 & 0.0625 \\
\hline C4. Stability of merchandise replenishment & -15.0104 & 14.0104 & 0.2390 \\
\hline C5. Level of supplier-customer cooperation & -5.3333 & 4.3333 & 0.0739 \\
\hline C6. Delivery cycle & -12.8429 & 11.8429 & 0.2020 \\
\hline Dj Summation & & $\mathbf{5 8 . 6 2 0 9}$ & \\
\hline Where: Ex: Entropy Dj: Dispersion of criterion j Wo: Target weight of criterion j \\
\hline
\end{tabular}

Source: modified from Alfonso Durán (2011).

In addition, the subjective weight (Ws) of the criteria is calculated by applying the Fuller's triangle method, (Agarski et al., 2012), by comparing the criteria in pairs, Table 3.

Table 3. Modified Fuller's Triangle method.

\begin{tabular}{lcccccc}
\multicolumn{1}{c}{ Criterios } & C1 & C2 & C3 & C4 & C5 & C6 \\
\hline C1. Merchandise availability & $\mathbf{1}$ & 1 & 1 & 1 & 1 & 1 \\
\hline C2. Quality level of the products supplied & 0 & $\mathbf{1}$ & $\mathbf{1}$ & $\mathbf{1}$ & 1 & 1 \\
\hline C3. Correspondence between quality-offer-price & 0 & 0 & $\mathbf{1}$ & 1 & 1 & 1 \\
\hline C4. Stability of merchandise replenishment & 0 & 0 & 0 & $\mathbf{1}$ & 1 & 1 \\
\hline C5. Level of supplier-customer cooperation & 0 & 0 & 0 & 0 & $\mathbf{1}$ & 1 \\
\hline C6. Delivery cycle & 0 & 0 & 0 & 0 & 0 & $\mathbf{1}$ \\
\hline
\end{tabular}

Source: modified from Alfonso Durán (2011).

The subjective Weight (Ps) of each criterion is calculated, from the assessment given by the specialists consulted, Table 4 .

Table 4. Determination of subjective weight (Ws) using the modified Fuller's Triangle method.

\begin{tabular}{lcc}
\multicolumn{1}{c}{ Criterios } & Summation & $\begin{array}{c}\text { Subjective weight } \\
\text { (Ws) }\end{array}$ \\
\hline C1. Merchandise availability & 6 & 0.2857 \\
\hline C2. Quality level of the products supplied & 5 & 0.2381 \\
\hline C3. Correspondence between quality-offer-price & 4 & 0.1905 \\
\hline C4. Stability of merchandise replenishment & 3 & 0,1429 \\
\hline C5. Level of supplier-customer cooperation & 2 & 0.0952 \\
\hline C6. Delivery cycle & 1 & 0.0476 \\
\hline Summation & 21 & \\
\hline
\end{tabular}

Source: adapted from Alfonso Durán (2011).

The determination of the definitive average weight $(\mathrm{Wd})$ of each of the identified criteria, for which the combinatorial method is used, which includes the objective (Wo) and subjective (Ws) weight of the previously calculated criteria (Table 5). 
Table 5. Weighting obtained from the combined method.

\begin{tabular}{lccc}
\hline \multicolumn{1}{c}{ Criterios } & $\begin{array}{c}\text { Target } \\
\text { weight } \\
\text { (Wo) }\end{array}$ & $\begin{array}{c}\text { Subjective } \\
\text { weight } \\
\text { (Ws) }\end{array}$ & $\begin{array}{c}\text { Definitive } \\
\text { weight } \\
\text { (Wd) }\end{array}$ \\
\hline C1. Merchandise availability & 0.2389 & 0.2857 & 0.2623 \\
\hline C2. Quality level of the products supplied & 0.1836 & 0.2381 & 0.2108 \\
\hline C3. Correspondence between quality-offer-price & 0.0625 & 0.1905 & 0.1265 \\
\hline C4. Stability of merchandise replenishment & 0.2390 & 0.1429 & 0.1909 \\
\hline C5. Level of supplier-customer cooperation & 0.0739 & 0.0952 & 0.0846 \\
\hline C6. Delivery cycle & 0.2020 & 0.0476 & 0.1248 \\
\hline Sum of Target Weights (Wo) for Subjective Weights $(W s)=1.0000$ & & \\
\hline
\end{tabular}

Source: adapted from Alfonso Durán (2011).

The set of suppliers is rated, for which, the elaboration of a supplier-criterion matrix is required, because of the evaluation of each of the suppliers $(\mathrm{Pi})$ under study (Table 6).

Table 6. Criterion-provider decision matrix.

\begin{tabular}{lcccccc}
\hline \multicolumn{1}{c}{ Provider (Pi) } & C1 & C2 & C3 & C4 & C5 & C6 \\
\hline P1. Food and beverage importer & 2 & 3 & 2 & 2 & 2 & 3 \\
\hline P2. Importer of food, beverages, cosmetics, hardware & 3 & 3 & 2 & 4 & 2 & 3 \\
\hline P3. Semi-finished food products & 4 & 3 & 2 & 3 & 2 & 2 \\
\hline P4. Pasta & 3 & 3 & 1 & 3 & 2 & 3 \\
\hline P5. Cosmetics & 4 & 3 & 2 & 4 & 2 & 4 \\
\hline P6. Juices and preserves & 4 & 2 & 2 & 4 & 2 & 3 \\
\hline P7. Meat & 3 & 3 & 2 & 3 & 2 & 3 \\
\hline P8. Jams & 3 & 3 & 2 & 3 & 2 & 3 \\
\hline
\end{tabular}

Source: Modified from Alfonso Durán (2011).

As a result of the criterion-supplier's decision matrix, we conclude that the analysed criteria are classified as maximizing. This shows that the suppliers that obtain a higher score are those that have a critical performance. Therefore, a homogenization process of the matrix is not justified. However, a standardization procedure of the criterionprovider's decision matrix was applied from the scale transformation method, in most decision-making contexts the units in which the different criteria are measured are usually vastly different, Table 7 .

Table 7. Standardized matrix.

\begin{tabular}{lcccccc}
\hline \multicolumn{1}{c}{ Provider $(\boldsymbol{P i})$} & C1 & C2 & C3 & C4 & C5 & C6 \\
\hline P1. Food and beverage importer & 0 & 0.5 & 1 & 0 & 0 & 0.5 \\
\hline P2. Importer of food, beverages, cosmetics, hardware & 0.5 & 0.5 & 1 & 0.6 & 0 & 0.5 \\
\hline P3. Semi-finished food products & 1 & 0.5 & 1 & 0.3 & 0 & 0 \\
\hline P4. Pasta & 0.5 & 0.5 & 0 & 0.3 & 0 & 0.5 \\
\hline P5. Cosmetics & 1 & 0.5 & 1 & 0.6 & 0 & 1 \\
\hline P6. Juices and preserves & 1 & 0 & 1 & 0.6 & 0 & 0.5 \\
\hline P7. Meat & 0.5 & 0.5 & 1 & 0.3 & 0 & 0.5 \\
\hline P8. Jams & 0.5 & 0.5 & 1 & 0.3 & 0 & 0.5 \\
\hline
\end{tabular}

Source: Modified from Alfonso Durán (2011). 
The weighted qualification of the suppliers was obtained, applying the weighted sum method described in Activity II.4. This step is carried out with the aim of identifying the most critical cases of suppliers according to the weighted qualification score, Table 8.

Table 8. Rating and order of critical suppliers.

\begin{tabular}{lcc}
\hline \multicolumn{1}{c}{ Provider $(\boldsymbol{P i})$} & Qualification & Order \\
\hline P1. Food and beverage importer & 0.2943 & 8 \\
\hline P2. Importer of food, beverages, cosmetics, hardware & 0.5400 & 6 \\
\hline P3. Semi-finished food products & 0.5515 & 5 \\
\hline P4. Pasta & 0.5000 & 7 \\
\hline P5. Cosmetics & $\mathbf{2 . 6 1 0 0}$ & $\mathbf{1}$ \\
\hline P6. Juices and preserves & $\mathbf{2 . 1 8 0 0}$ & $\mathbf{3}$ \\
\hline P7. Meat & 0.8400 & 4 \\
\hline P8. Jams & $\mathbf{2 . 4 3 0 0}$ & $\mathbf{2}$ \\
\hline
\end{tabular}

Source: Modified from Alfonso Durán (2011).

The suppliers that obtain the highest score in the weighted qualification become the critical cases: P5. cosmetics (2.61); Q8. jams (2.43); finally, P6. juices and preserves (2.18). This does not mean that they are worthless suppliers, only that they supply basic products for the client and require continuous improvement actions to contribute to the performance of the commercial chain. Suppliers present some difficulties, which focus on the instability of national suppliers and the payment to international ones, as well as the disorientation between the client's needs and the purchasing process.

The improvement actions focused on the design of collaborative planning between suppliers and the commercial chain; drawing up a joint business plan; apply the criteria matrix procedure to the suppliers with the greatest impact on sales and evaluate suppliers based on service given to the customer.

The proposal for collaboration is based on the selection of suppliers in an integrated way. The needs of the clients are considered, as well as the analysis of the demand for the selected products. This was done to estimate the horizon to be planned as presented in (Activity III.1). This procedure is defined, to allow its systematization:

- Collect historical data on the demand for the products of each retail chain.

- Consolidate the sales data of each retail chain in a single value.

- Analyse the behavior of demand in previous periods using statistical packages.

- Forecast the demand for the planning horizon.

- Perform the goodness-of-fit test of the predicted data to know what probability distribution it represents.

- Carry out a qualitative analysis of the forecast, through consultation with specialists on the calculation obtained, to validate if the results obtained correspond to what was expected.

Otherwise, some changes in the historical pattern must be predicted; which allows to establish the true forecast of the demand, when considering the existence of external factors that affect the historical behavior of the forecast, which must be included at that time. 
In the development of the procedure, the weight of each product family and its representation in the value of total demand must be calculated (Equation 2).

$$
W f(d)=\sum_{f=1}^{s}(V p)(V d)
$$

Where:

Wf (d): Weighted value of each family of products in the final demand, $f=1, \ldots, s$

$\mathrm{Vd}$ : Demand value, $\mathrm{d}=1, \ldots, \mathrm{m}$

$V p$ : Percentage value of each family of products, $p=1, \ldots, n$

With this previous value, the weight of each product family in the final demand is related to the replacement of supplies and the main suppliers, where the percentage value of the product in demand and the main suppliers that must guarantee them for sale are identified. Another point is to establish a weight in relation to each supplier, for which the modified Fuller's Triangle method is used again. Once the weights for the $\mathrm{k}$ suppliers, W1, W2, ..., Ws are determined, the demand to be distributed by each supplier (Dp) is calculated, using the following mathematical expression (Equation 3):

$$
D p=\sum_{k=1}^{s}(W k)(V d)(N)
$$

(Equation 3)

Where:

Wk: Valor ponderado del suministrador $\mathrm{k}$ correspondiente a la familia de productos, $k=1, \ldots, s$

$\mathrm{N}$ : Número de suministradores.

$\mathrm{Vd}$ (familia): valores de la demanda de cada familia de productos, $\mathrm{d}=1, \ldots, \mathrm{m}$

Finally, once the demand to be distributed by each supplier $(D p)$ is determined, the operating variables of the system provided by said forecast model are selected, considering when and how much to distribute. It is suggested that senior management, on an ongoing basis, ensure application and vendor allocation. Regarding the parameters, they vary depending on the results of logistics processes. For example, supplier demand, as well as noticeable differences in customer needs.

Then, we proceed to the selection of different methods and forms of information exchange in relation to the products. This is done with the objective of guaranteeing for each supplier the requested demand. In addition, to consider some random elements that may be present in the market. On the other hand, in the case of centralized planning (object of study), the responsible actor delivers the information to a coordinator who makes the best decisions for the group and communicates them to each node (Hernández Hormazabal, 2011).

The study of collaborative supplier's management in source chains presents different perspectives: from the management of stakeholders and their processes to achieving the objective of the chain (Miyazhdenovna et al., 2020), the variables of sustainability, innovation (Li et al., 2020) and optimization of management (supply, demand, production capacity, customer service, costs, cycles, inventory), the development of the Scor model and within this, the supplier process. On the other hand, the use of philosophies that promote collaborative supplier management such as: CPFR for its acronym in English Collaborative Planning Forecasting and Replenishment (Karadayi-Usta, 2020) and SRM for its acronym in English Supplier 
Relationship Management (Adesanya et al., 2020). Along with the development of technologies that favours quickness and traceability in this process specifically (AmpeN'Da et al., 2020). Despite this variety, there are gaps aimed at its application in some contexts and its form of implementation (methodology), as is the case of the Cuban commercial chain. The incorporation of collaborative management allows a better approach between the needs of customers, the market and the products offered by the chain (problem under study).

\section{Conclusions}

1. Supplier's management is an aspect that has a decisive influence on a retail chain under study, which demonstrates the need to implement a more efficient method for its operation based on the requirements and needs of customers, promoting collaborative supplier management through the application of multi-criteria methods.

2. The results of the implementation of the procedure are specified in the analysis of the current situation of the performance of suppliers, the identification of the criteria for the evaluation and selection, as well as the strategies for the distribution and commercialization of products and services to customers.

3. The application of the procedure shows in this case study, the non-interrelation between customers' demand and the suppliers' purchase, such as the customers' dissatisfaction in the chain under study. As a consequence of these deficiencies, the use of collaborative planning among suppliers is proposed to promote a joint business plan that impacts the customers' service process and the competitiveness of the retail commercial chain in Cuba.

Finally, it is recommended to carry out pertinent studies for the application of the procedure and the multicriteria methods detailed in the development of the article in other retail chains. Similarly, it is suggested to proceed with its systematic evaluation as well as the elaboration of programs and improvement plans in the distribution carried out by the different suppliers. The objective is to facilitate the compliance of the collaborative management between the client and the supplier.

\section{References}

Acevedo Suárez, J. A. La logística moderna en la empresa. La Habana. Cuba: Editorial Félix Varela, 2017.

Adamu Nandonde, F., \& Kuada, J. (2016). Modern food retailing buying behaviour in Africa: the case of Tanzania. British Food Journal, 118(5), 1163-1178.

Adesanya, A., Yang, B., Bin Iqdara, F. W., \& Yang, Y. (2020). Improving sustainability performance through supplier relationship management in the tobacco industry. Supply Chain Management, 25(4), 413-426. http://dx.doi.org/10.1108/SCM-01-2018-0034.

Agarski, B., Budak, I., Kosec, B., \& Hodolic, J. (2012). An approach to multi-criteria environmental evaluation with multiple weight assignment. Environmental Modeling and Assessment, 17(3), 255-266. http://dx.doi.org/10.1007/s10666-011-9294-y.

Alfonso Durán, A. (2011). Análisis de la gestión de proveedores de la Sucursal, Matanzas. Cuba: Ingeniería Industria, Universidad de Matanzas"Camilo Cienfuegos". 
Alfonso Villaquirán, V., \& Ospina, Y., No. (2016). Sistema de gestión de calidad, factor importante para el desarrollo laboral del colaborador de Unisalud Palmira. Colección Académica de Ciencias Estratégicas, 3(1), 41-60.

Alzate Rendón, I. C. (2015). Selección y certificación de proveedores: un camino hacia el mejoramiento de la gestión de la cadena de suministro. Escenarios: Empresa y Territorio, 4(4), 205-230.

Ampe-N'Da, L. D., Payne, B. A., Spake, R. I., Sharpe, S., \& Arora, A. (2020). Buyer-supplier relationships: role of collaboration, sustainability, and technology. In A. Saxena Arora, S. Bacouel-Jentjens, M. Sepehri \& A. Arora (Eds.), Sustainable innovation: trends in marketing and management (pp. 47-58). Cham: Springer International Publishing. http://dx.doi.org/10.1007/978-3-030-30421-8_5.

Barreiros Porto, R. (2016). The commercial cycle from the viewpoint of operant behavioral economics: effects of price discounts on revenues received from services. Revista $A D M$, 51(3), 310-322.

Calache, L. D. D. R., Pedroso, C. B., Lima, F. R., Jr., \& Carpinetti, L. C. R. (2019). Proposta de um modelo de avaliação e de seleção de fornecedores de manutenção industrial utilizando Fuzzy-TOPSIS. Gestão \& Produção, 26(2), e3565. http://dx.doi.org/10.1590/0104-530x3565-19.

Calle Vicente, A. D. L., Barinaga Naves, A., \& Gietz Jimenez, J. C. (2016). La colaboración como estrategia en la cadena de suministro: una visión metodológica. Dyna Magement, 4(1), 1-9. http://dx.doi.org/10.6036/MN7809.

Cano Olivos, P., Carrasco, F. O., Flores, J. L. M., Moreno, Y. M., \& Nava, G. L. (2015). Modelo de gestión logística para pequeñas y medianas empresas en México. Contaduría y Administración, 60(1), 181-203. http://dx.doi.org/10.1016/S0186-1042(15)72151-0.

Castro Castell, O. (2015). Gestión de la cadena de abastecimiento para la competitividad empresarial. Sinapsis, 7(7), 102-107.

Dávila Aragón, G., Ortiz Arango, F., \& Cruz Aranda, F. (2016). Cálculo del valor en riesgo operacional mediante redes bayesianas para una empresa financiera. Contaduría y Administración, 61(1), 176-201. http://dx.doi.org/10.1016/j.cya.2015.09.009.

De La Hoz Granadillo, E. J., Morelos Gomez, J., \& Fontalvo Herrera, T. J. (2016). Gestión logística de las pequeñas y medianas empresas (PYMES) de confecciones en el departamento del Atlántico. Desarrollo Gerencial, 4(2), 47-71.

De Sousa Batista, P. C., Lisboa, J. V. O., Augusto, M. G., \& Almeida, F. E. B. (2016). Effectiveness of business strategies in Brazilian textile industry. Revista ADM, 51(2), 225239.

Duke, V. O., Navarro, M., Díaz, G., Pérez, Y., \& Vargas-Lombardo, M. (2017). Exploración en los sistemas CRM/ERP como estrategia en el sector PYMES. Revista de Iniciación Cientifica, 2(2), 86-94.

Fergusson Álvarez, L. A., Valdés Ferrer, D., \& Parada Gutiérrez, O. (2016). Procedimiento de diagnóstico de la gestión logística para entidades turísticas. Anuario Facultad de Ciencias Económicas y Empresariales, 1, 91-109.

Freitas, D. C. D., Oliveira, L. G. D., \& Alcântara, R. L. C. (2019). A theoretical framework to adopt collaborative initiatives in supply chains. Gestão \& Produção, 26(3), e4194. http://dx.doi.org/10.1590/0104-530x-4194-19.

García Alcaraz, J. L., Alvarado Iniesta, A., \& Maldonado Macías, A. A. (2008). Selección de proveedores basada en análisis dimensional. Contaduría y Administración, 58(3), 249-278.

Galarza Molina, S.L, Torres, A., Méndez Fajardo, S., \& Pérez Muzuzu, B.C. (2011). Herramienta de análisis multicriterio como soporte para el diseño del programa social de la Facultad de Ingeniería. Estudios Gerenciales, 27 (121), 175-194. 
Gil Saura, I. G., Ruiz Molina, M. E., \& Calderón García, H. (2009). La influencia de las TIC en la Satisfacción del Cliente en el Comercio Minorista. Cuadernos Americanos, 120(3592), 22.

González Correa, J. A. (2016). Contratación logística en Colombia: implementación de un operador logístico integral. Semestre Económico, 18(38), 215-238.

Hazen, B. T., Boone, C. A., Wang, Y., \& Khor, K. S. (2016). Perceived quality of remanufactured products: construct and measure development. Journal of Cleaner Production, 142(pt 2), 716-726.

Hernández Hormazabal, J. (2011). Propuesta de una arquitectura para el soporte de la Planificación de la Producción Colaborativa en Cadenas de Suministro tipo árbol (Tesis Doctoral). Departamento de Organización de Empresas, Universidad Politécnica de Valencia, Valencia. http://dx.doi.org/10.4995/Thesis/10251/14571.

Hernández, O., Aguilera Enriquez, L., \& González Adame, M. (2016). Efecto Gestión de la Cadena de Suministro en el desempeño de Pyme Manufacturera. Aguascalientes, México. Amazonia Investiga, 5(8), 22-31.

Holweg, M., Disney, S., Holmström, J., \& Småros, J. (2005). Supply chain collaboration: making sense of the strategy continuum. European Management Journal, 23(2), 170-181.

Infantes Díaz, Y., Martínez Vivar, R., \& Sánchez Rodríguez, A. (2015). Gestión comercial desde un enfoque prospectivo. Entelequia: Revista Interdisciplinar, 18, 143-166.

Karadayi-Usta, S. (2020). An interpretive structural fuzzy analysis for CPFR implementation barriers: a food supply chain case study. In C. Kahraman, S. Cebi, S. Cevik Onar, B. Oztaysi, A. Tolga \& I. Sari (Eds.), Intelligent and Fuzzy Techniques in Big Data Analytics and Decision Making. INFUS 2019. Advances in Intelligent Systems and Computing (Vol. 1029, pp. 423-431). Cham: Springer. http://dx.doi.org/10.1007/978-3-030-23756-1_53.

Kotler, P. (2016). Marketing Insights from A to Z-80 Concepts Every Manager Needs to Know. Hoboken: Wiley.

Li, G., Yu, G., Wang, S., \& Yah, H. (2017). Bullwhip and anti-bullwhip effects in a supply chain. International Journal of Production Research, 55(18), 5423-5434. http://dx.doi.org/10.1080/00207543.2017.1319087.

Li, Q., Kang, Y., Tan, L., \& Chen, B. (2020). Modeling formation and operation of collaborative green innovation between manufacturer and supplier: a game theory approach. Sustainability, 12(6), 2209. http://dx.doi.org/10.3390/su12062209.

López Torres, M. D. J., \& Ortega Hernández, A. (2017). Modelo estadístico de calidad para la medición y control de calidad de matices y teñidos en la cadena productiva de telas. caso de estudio: tejidos Gaytán Sa de CV. Jóvenes en la Ciencia, 2(1), 702-706.

Melo, D. D. C., \& Alcântara, R. L. C. (2015). Um modelo da maturidade da gestão da demanda: um estudo multicaso na cadeia de suprimento de produtos de mercearia básica. Gestão \& Produção, 22(1), 53-66. http://dx.doi.org/10.1590/0104-530X0701-13.

Miyazhdenovna, N., Zhaslanovna, S. E., Anuarbekkyzy, G. N., Nurlanovna, L. A., \& Tulegenovna, K. Z. (2020). The role of management accounting techniques in determining the relationship between purchasing and supplier management: a case study of retail firms in Kazakhstan. Uncertain Supply Chain Management, 8(1), 149-164. http://dx.doi.org/10.5267/j.uscm.2019.7.008.

Muñoz Aguilar, R. A., \& Roldan Zuluaga, S. (2016). Competitividad y cadenas de abastecimiento en el sector productivo del valle del Cauca, Colombia. Revista Global de Negocios, 4(1), 77.

Quang, H. T., Sampaio, P., Carvalho, M. S., Fernandes, A. C., Binh An, D. T., \& Vilhenac, E. (2016). An extensive structural model of supply chain quality management and firm performance. International Journal of Quality \& Reliability Management, 33(4), 444-464. http://dx.doi.org/10.1108/IJQRM-11-2014-0188. 
Ripoll Feliu, V., \& Dickinson González, Y. (2015). Propuesta de un procedimiento para el proceso de planificación del inventario en la cadena hotelera Gran Caribe. Harvard Deusto Business Research, 4(1), 46-60. http://dx.doi.org/10.3926/hdbr.50.

Sacomano, M., No., \& Pires, S. R. I. (2012). Medição de desempenho em cadeias de suprimentos: um estudo na indústria automobilística. Gestão \& Produção, 19(4), 733-746. http://dx.doi.org/10.1590/S0104-530X2012000400006.

Sarache Castro, W. A., Castrillón Gómez, Ó. D., \& Ortiz Franco, L. F. (2009). Selección de proveedores: una aproximación al estado del arte. Cuadernos de Administración, 22(38), 145-168.

Silva, V. P. R., Belo, A. F., Fo., Singh, V. P., Almeida, R. S. R., Silva, B. B., de Sousa, I. F., \& Holanda, R. M. (2017). Entropy theory for analysing water resources in northeastern region of Brazil. Hydrological Sciences Journal, 62(7), 1029-1038. http://dx.doi.org/10.1080/02626667.2015.1099789.

Urbano Guerrero, L. C., Muñoz Marín, L. S., \& Osorio Gómez, J. C. (2016). Selección multicriterio de aliado estratégico para la operación de carga terrestre. Estudios Gerenciales, 32(138), 35-43. http://dx.doi.org/10.1016/j.estger.2015.09.002.

Uribe Macías, M. E., Orjuela Ramírez, D. F., \& Moreno Barragán, X. (2016). RSE de la Universidad del Tolima frente al stakeholder "proveedores". Dimensión Empresarial, 14(2), 115-128.

Viana, F. L. E., Barros, J. D. P., No., \& Añez, M. E. M. (2014). Gestão da cadeia de suprimento e vantagem competitiva relacional nas indústrias têxtil e de calçados. Gestão \& Produção, 21(4), 836-852. http://dx.doi.org/10.1590/0104-530X1350/14.

Vieira, V. A., \& Bonifácio da Silva, W. (2016). An analysis of the relationship between embedded ties and supplier innovation in the cooperative sector. Revista ADM, 51(4), 386396.

Vizzoto, F. \& Caixeta, J. V., Fo. (2019). Demand relaxation in supplier selection processes. Gestão \& Produção, 26(4), e3826. http://dx.doi.org/10.1590/0104-530x3826-17.

Wang, X., Zhang, Y., Yang, Y., \& Ge, G. (2017). New bounds of permutation codes under Hamming metric and Kendall's T -metric. Designs, Codes and Cryptography, 85(3), 533545. http://dx.doi.org/10.1007/s10623-016-0321-5. 